\title{
CORRIGENDUM
}

\section{Changes in land use alter the structure of bacterial communities in Western Amazon soils}

Ederson da C Jesus, Terence L Marsh, James M Tiedje and Fatima M de S Moreira

The ISME Journal (2009) 3, 1222; doi:10.1038/ismej.2009.98

Correction to: The ISME Journal (2009) 3, 1004-1011; doi:10.1038/ismej.2009.47

Since the publication of this paper, the authors have noticed an error in the accession numbers on page 2 . The correct text is shown here.

The authors would like to apologise for this error.
Libraries were built for samples from primary forest (GenBank accession no. FJ024502-024588 and FJ036978-FJ037063), old secondary forest (GenBank accession no. FJ037064-FJ037232), pasture (GenBank accession no. FJ037233-FJ037389) and crops (GenBank accession no. FJ037390-FJ037544) sites. 